\title{
Analysis of Using Ultraviolet Light to Test Color Mothball
}

\author{
Shen-Kung Liao ${ }^{*}$, Chung-Tse $\mathrm{Wu}^{1}$, Chia-Chi Yang1, Wen-Chang Chen ${ }^{2}$, Tien-Yuan Liang ${ }^{2}$ \\ ${ }^{1}$ Department of Fiber and Composite Materials, Feng Chia University, Taiwan \\ ${ }^{2}$ Environmental Bioengineering \& Chemical Analysis Section, China Steel Corporation, Taiwan \\ Email: ^skliao@fcu.edu.tw, spadea83771@gmail.com, ttps30411@gmail.com, t641@mail.csc.com.tw, ykliang@mail.csc.com.tw
}

How to cite this paper: Liao, S.-K., $\mathrm{Wu}$, C.-T., Yang, C.-C., Chen, W.-C. and Liang, T.-Y. (2018) Analysis of Using Ultraviolet Light to Test Color Mothball. Journal of Textile Science and Technology, 4, 129-140. https://doi.org/10.4236/jtst.2018.44009

Received: October 11, 2018

Accepted: November 18, 2018

Published: November 22, 2018

Copyright ( 92018 by authors and Scientific Research Publishing Inc. This work is licensed under the Creative Commons Attribution International License (CC BY 4.0).

http://creativecommons.org/licenses/by/4.0/

(c) (i) Open Access

\begin{abstract}
Color mothball is a daily necessity in Southeast Asia. Mothball contained nearly $100 \%$ naphthalene or $100 \%$ p-dichlorobenzene. It was used to resist insects, mothproof and mildew with a special odor. In other words, the odor was thought unpleasant enough to drive animals away in repellent products. This research analyzed color mothball which was manufactured by $\mathrm{C}$ and $\mathrm{N}$ companies. The mothball was dyed with eight dyes and three essences of fragrance, respectively. The experiment of color fastness with UV-light test is to determine how much the color will fade, when it exposed to a known ultraviolet light source. In the last analysis, the experimental data from the spectrum of GC/MS described all kinds of structure on color mothball after 80 hours phototherapy treatment as shown in the content. This research reveals that color mothball can have better appearance and greater performance, to meet the requirements for customs and various applications.
\end{abstract}

\section{Keywords}

Naphthalene, Quinoline, Color, Fade, Whiteness

\section{Background}

Color Mothball is used to prevent insect and mothproof with a special odor and it is a daily necessity. It was sold to advanced and developed countries worldwide. However, color mothball is sold to Southeast Asia such like Malaysia, Singapore, and Indonesia in recent years. The reason is that Southeast Asia has more insect and mildew than occident. Thus, color mothball has wide market in Southeast Asia.

White mothball is very common in daily life of Europe and America. In the United States, there are nine insect repellent products containing naphthalene 
that have been registered for use by the US Environmental Protection Agency. These include products intended to kill moths in airtight spaces, and to repel vertebrate pests in attics and wall void spaces, even though it is not so popular in Southeast Asia [1] [2]. Because the people in Southeast Asia prefer to use the mothball with various color and strong fragrance, the dyeing technology of mothball have been researched in these years.

This research analyzed the color mothball which was manufactured by China Steel Corporation and Japan Corporation. Let the color mothball with dyed of eight dyes (Four yellow, two red and two green) and fragrance of three essences (sunflower, ginger lily and lavender of essences) respectively. The experiment of color fastness with light test is to determine how much the color will fade when exposed to a known ultraviolet light source. In the research, we try to find a good dyestuff which owned the highest level of light fastness with Kubelka-Munk equation and color spaces of CIE Lab \& CIE LCH. In the last analysis, the experiment determined of fragrance structure from Fourier transformed infrared spectroscopy (FT-IR). In addition, we researched into composition of color mothball with different company from gas chromatography-mass spectrometry (GC/MS) and described kinds of structure after 80 hours light test phototherapy treatment [3].

The mothball had the better of color fastness by FT-IR and GC/MS analyzed. That's just what we expected. In other word, this research reveals the mothball with various colors, better appearance and greater performance in order to satisfy the requirements for market and various applications [4].

\section{Experimental Measurement}

\subsection{Kubelka-Munk Theory (K/S)}

We should use K/S where $\mathrm{K}$ is the absorption coefficient, $S$ is the scattering coefficient of light in the visible region $(400-700 \mathrm{~nm})$ and $R_{\infty}$ is reflectance value in maximum absorption wave length $(\mathrm{nm})$ to evaluate the color strength for dye samples. In 1948, Kubelka developed numerous formulas for correlating reflectance with concentration by making scattering and surface difference corrections. It was found that the ratio of light absorption to light scattering at a given wavelength is proportional to the concentration of the dye in the sample. The relationship shown here is derived from the Kubelka-Munk equation [5] [6]:

$$
\frac{K}{S}=\frac{\left(1-R_{\infty}\right)^{2}}{2 R_{\infty}}
$$

Figure 1 shows the light of incident is $I$, thickness of $d x$ of scattering is $I^{\star} S^{\star}$ $d x$ and parts of transmission is $I^{\star}(1-S-K) * d x$.

\subsection{Color Spaces of CIE LAB \& CIE LCH}

CIE $L^{*} a^{*} b^{*}$ (CIE LAB) and CIE $L^{*} C^{*} H^{*}$ (CIE LCH) are color space specified by the CIE International Commission on Illumination. It describes all the visible 


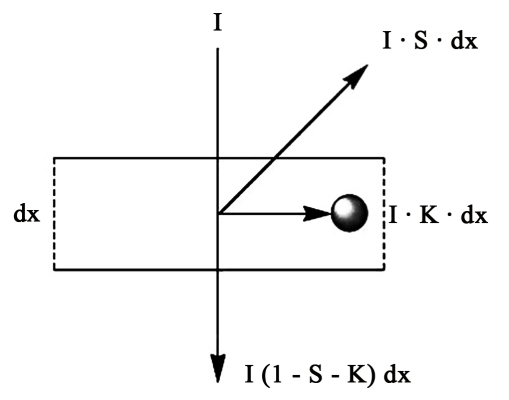

Figure 1. The relation of physical absorption and scattering.

colors visible to the human eye and was created to serve as a device independent model to be used as a reference. Figure 2 and Table 1 shows the three coordinates of CIE LAB represent the lightness of the color $\left(\mathrm{L}^{*}=0\right.$ yields black and $\mathrm{L}^{*}$ $=100$ indicates diffuse white; specular white may be higher), its position between red/magenta and green $\left(\mathrm{a}^{\star}\right.$, negative values indicate green while positive values indicate magenta) and its position between yellow and blue ( $b^{*}$, negative values indicate blue and positive values indicate yellow).

Another $\mathrm{CIE} \mathrm{L}^{\star} \mathrm{C}^{\star} \mathrm{H}^{\star}(\mathrm{CIE} \mathrm{LCH})$ is $\mathrm{L}^{\star}$ axis represents Lightness. It ranges from $L^{*}=0$ yields black and $L^{*}=100$ indicates diffuse white. The $C^{*}$ axis represents Chroma or "saturation". This ranges from 0 at the centre of the circle, which is completely unsaturated (i.e. a neutral grey, black or white) to 100 or more at the edge of the circle for very high Chroma (saturation) or "color purity". $\mathrm{H}^{\star}$ describes the hue angle. It ranges from 0 to 360 and $\mathrm{H}^{*}=0^{\circ}=\mathrm{red} / \mathrm{H}^{*}=$ $90^{\circ}=$ yellow $/ \mathrm{H}^{\star}=180^{\circ}=$ green $/ \mathrm{H}^{\star}=270^{\circ}=$ blue .

\subsection{Production Process of Color Mothball}

As below figure.

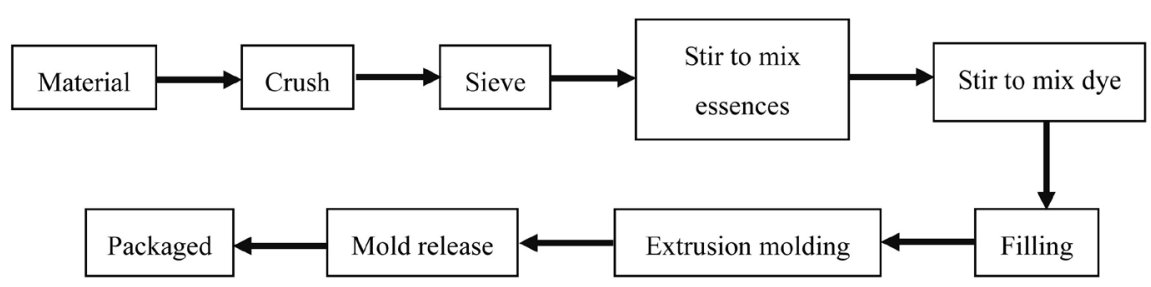

\section{Results and Discussion}

Tables 2-4 show the K/S data of color mothball for initial and after UV-light test from different color series. Color mothball was manufactured from $\mathrm{N}$-company and C-company with dyed of six dyes (Two yellow, two green and two red of dye.) and three essences of fragrance(sunflower, ginger lily and lavender of essences), respectively Figure 3 shows the difference of K/S value $(\Delta K / S)$ in color mothball between initial and after UV-light test. Through the experiment, mothball after UV-light test, the color was darker than initial. We can estimate the appearance is caused by the volatility matter of color mothball. In other 

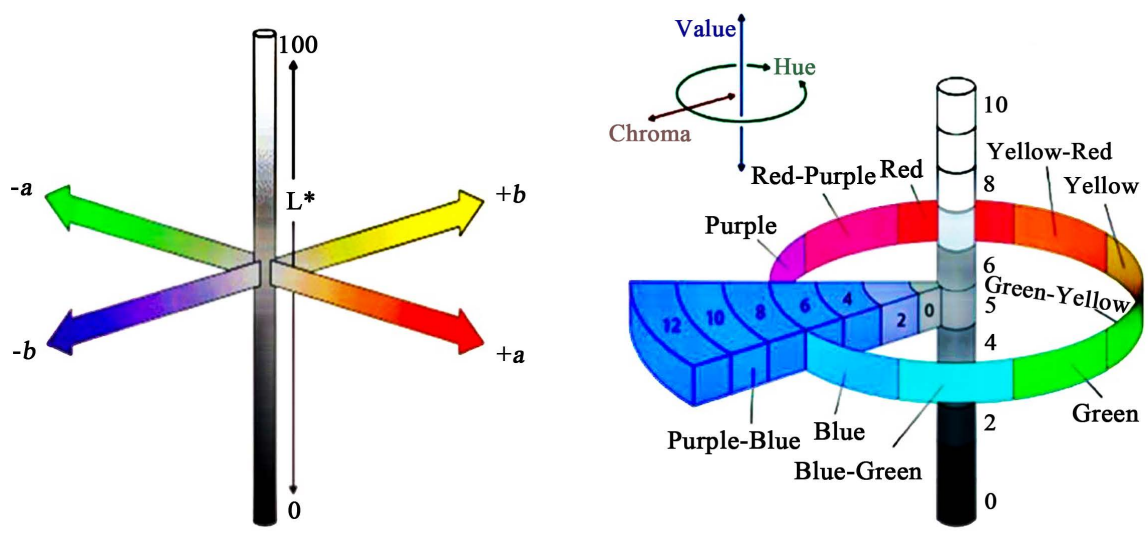

Figure 2. The CIE $\mathrm{L}^{\star} \mathrm{a}^{\star} \mathrm{b}^{\star} \& \mathrm{CIE} \mathrm{L}^{\star} \mathrm{C}^{\star} \mathrm{H}^{\star}$ color model [7].

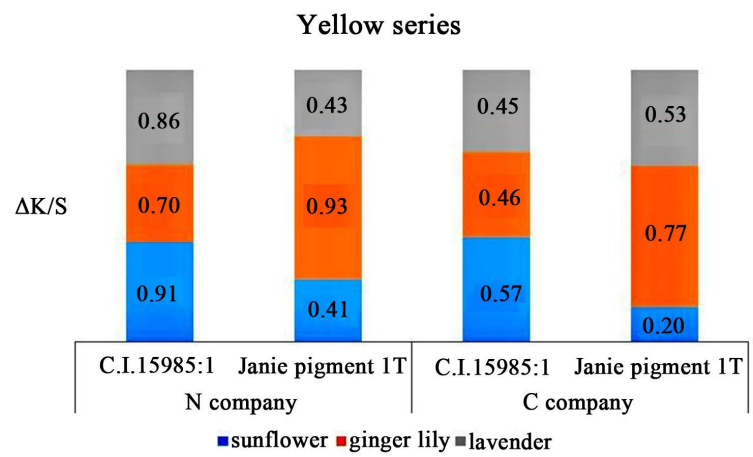

(a)

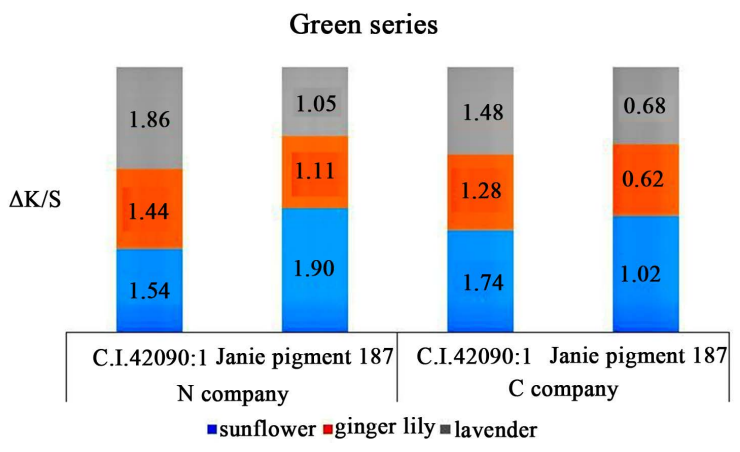

(b)

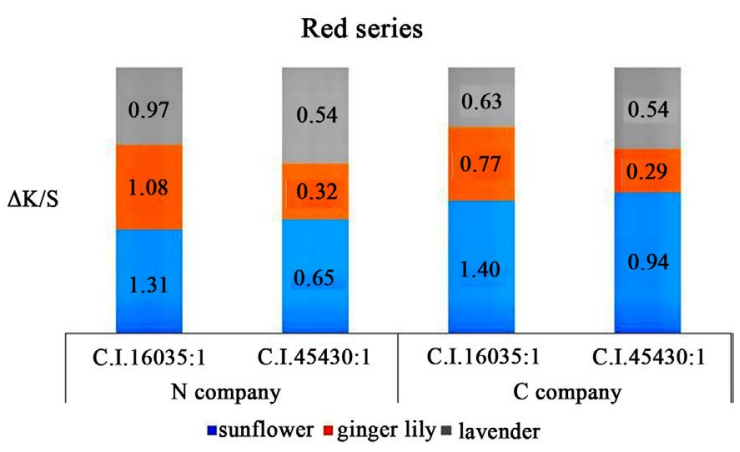

(c)

Figure 3. Comparison of the difference of K/S value in color mothball for initial and after UV-light test. (a) Yellow series (b) green series (c) red series. 
Table 1. Explanation of $L^{*}, a^{*}, b^{\star}, C^{*}, H^{*}$.

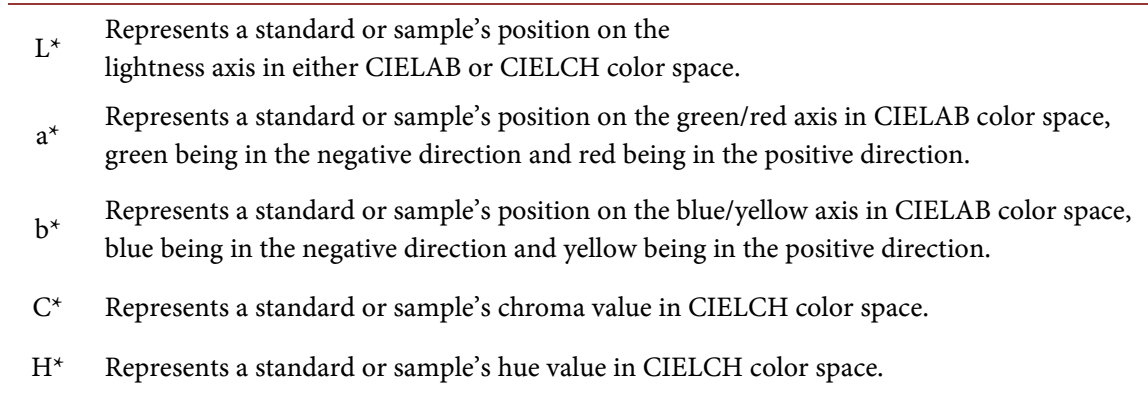

Table 2. The K/S data of color mothball for initial and after UV-light test from yellow series dye.

\begin{tabular}{cccccc}
\hline \multirow{2}{*}{ Essence } & Color strength & \multicolumn{5}{c}{ Dye } \\
\cline { 3 - 6 } & \multicolumn{2}{c}{ Company } & \multicolumn{2}{c}{ C.I. 15985:1 } & \multicolumn{2}{c}{ Janie pigment 1T } \\
\hline \multirow{2}{*}{ sunflower } & $(\mathrm{K} / \mathrm{S})_{\text {initial }}$ & 0.4786 & 0.6388 & 1.7955 & 1.2789 \\
& $(\mathrm{~K} / \mathrm{S})_{\text {after }}$ & 1.3880 & 1.2082 & 2.2092 & 1.4772 \\
\multirow{2}{*}{ ginger lily } & $(\mathrm{K} / \mathrm{S})_{\text {initial }}$ & 0.5033 & 0.4171 & 2.0213 & 1.3303 \\
& $(\mathrm{~K} / \mathrm{S})_{\text {after }}$ & 1.1996 & 0.8793 & 2.9514 & 2.1019 \\
lavender & $(\mathrm{K} / \mathrm{S})_{\text {initial }}$ & 0.5429 & 0.4985 & 2.0449 & 1.5337 \\
& $(\mathrm{~K} / \mathrm{S})_{\text {after }}$ & 1.4056 & 0.9438 & 2.4759 & 2.0637 \\
\hline
\end{tabular}

Table 3. The K/S data of color mothball for initial and after UV-light test from green series dye.

\begin{tabular}{|c|c|c|c|c|c|}
\hline \multirow{3}{*}{ Essence } & \multirow{2}{*}{ Color strength } & \multicolumn{4}{|c|}{ Dye } \\
\hline & & \multicolumn{2}{|c|}{ C.I. $42090: 1$} & \multicolumn{2}{|c|}{ Janie pigment 187} \\
\hline & Company & $\mathrm{N}$ & $\mathrm{C}$ & $\mathrm{N}$ & $\mathrm{C}$ \\
\hline \multirow{2}{*}{ sunflower } & $(\mathrm{K} / \mathrm{S})_{\text {initial }}$ & 0.6511 & 0.5705 & 0.9479 & 0.7159 \\
\hline & $(\mathrm{K} / \mathrm{S})_{\mathrm{after}}$ & 2.1928 & 2.3083 & 2.8471 & 1.7404 \\
\hline \multirow{2}{*}{ ginger lily } & $(\mathrm{K} / \mathrm{S})_{\text {initial }}$ & 0.4653 & 0.4101 & 1.1214 & 1.0618 \\
\hline & $(\mathrm{K} / \mathrm{S})_{\mathrm{after}}$ & 1.9078 & 1.6916 & 2.2313 & 1.6828 \\
\hline \multirow{2}{*}{ lavender } & $(K / S)_{\text {initial }}$ & 0.3454 & 0.3601 & 1.324 & 0.8127 \\
\hline & $(\mathrm{K} / \mathrm{S})_{\mathrm{after}}$ & 2.2023 & 1.8409 & 2.3691 & 1.4884 \\
\hline
\end{tabular}

Table 4. The K/S data of color mothball for initial and after UV-light test from red series dye.

\begin{tabular}{|c|c|c|c|c|c|}
\hline \multirow{3}{*}{ Essence } & \multirow{3}{*}{ Color strength } & \multicolumn{4}{|c|}{ Dye } \\
\hline & & \multicolumn{2}{|c|}{ C.I. $16035: 1$} & \multicolumn{2}{|c|}{ C.I. $45430: 1$} \\
\hline & & $\mathrm{N}$ & $\mathrm{C}$ & $\mathrm{N}$ & $\mathrm{C}$ \\
\hline \multirow{2}{*}{ sunflower } & $(\mathrm{K} / \mathrm{S})_{\text {initial }}$ & 0.5916 & 0.565 & 0.733 & 0.4622 \\
\hline & $(\mathrm{K} / \mathrm{S})_{\text {after }}$ & 1.9008 & 1.9687 & 1.3869 & 1.4033 \\
\hline \multirow{2}{*}{ ginger lily } & $(\mathrm{K} / \mathrm{S})_{\text {initial }}$ & 0.3362 & 0.3485 & 0.6961 & 0.5956 \\
\hline & $(\mathrm{K} / \mathrm{S})_{\mathrm{after}}$ & 1.4121 & 1.1147 & 1.0141 & 0.8896 \\
\hline \multirow{2}{*}{ lavender } & $(\mathrm{K} / \mathrm{S})_{\text {initial }}$ & 0.3976 & 0.4598 & 0.4244 & 0.4244 \\
\hline & $(\mathrm{K} / \mathrm{S})_{\mathrm{after}}$ & 1.3693 & 1.0882 & 0.9678 & 0.9678 \\
\hline
\end{tabular}


words, unit volume of dye in color mothball is increased. Thus K/S value is increased after UV-light test.

In Figure 3, we can find color mothball have regularities at $\mathrm{K} / \mathrm{S}$ value in dyes and essences, no matter what $\mathrm{N}$ or $\mathrm{C}$ company product. We need to rely on $\mathrm{K} / \mathrm{S}$ to evaluate the color strength for dye samples. Such as color mothball use yellow dye of Janie pigment 1T with sunflower essences, green dye of Janie pigment 187 with lavender essences have better color fastness and red dye of C.I. 45430:1 with ginger lily essences have better color fastness.

From the above results, we select color mothball dyed with Janie pigment $1 \mathrm{~T}$ of yellow series, C.I. 45430:1 of red series and Janie pigment 187 of green series. Figure 4 shows the color mothball difference in $\mathrm{L}^{*}, \mathrm{a}^{\star}, \mathrm{b}^{*}$ and $\mathrm{c}^{\star}$ value between initial and after UV-light test. The research mainly discusses lightness $\left(\mathrm{L}^{\star}\right)$, red/green values $\left(a^{*}\right)$, yellow/blue values $\left(b^{*}\right)$ and Chroma $\left(C^{*}\right)$. As shown in Figure 5, we can find color mothball that have regularities at $\mathrm{L}^{*}, \mathrm{a}^{\star}, \mathrm{b}^{*}$ and $\mathrm{C}^{\star}$ value in the same dyes and essences, no matter what $\mathrm{C}$ or $\mathrm{N}$ company product. Mothball used dye of Janie pigment $1 \mathrm{~T}$ with sunflower essences, C.I. 45430:1 with ginger lily essences and Janie pigment 187 with lavender essences have the better color fastness.

Figures 5-7 showed the fragrance of three essences (sunflower, ginger lily and lavender of essences) analyzed by using FT-IR. We could find the three essences have carboxyl structure from vibration of $\mathrm{O}-\mathrm{H}$ bond at wavelength range from 3400 to $3200 \mathrm{~cm}^{-1}$ [8], the rotation of $\mathrm{C}=\mathrm{O}$ bond at wavelength range from 1685 to $1660 \mathrm{~cm}^{-1}$ [9] and rotation of $\mathrm{C}-\mathrm{O}$ bond at wavelength range from 1410 to $1310 \mathrm{~cm}^{-1}$ [10]. In addition, essences have long alkyl group and vibration of C-F bond at wavelength range from 1350 to $1140 \mathrm{~cm}^{-1}$ [11] [12]. Table 5 showed variety of vibration and rotation group from Fourier transform infrared spectroscopy.

From gas chromatography-mass spectrometry (GC/MS) for $\mathrm{N}$ and C company product. The initial compositions of color mothball from $\mathrm{C}$ and $\mathrm{N}$ company product, as shown in Table 6. Because the composition of the mothballs produced by each company is different, we must discuss whether the different ingredients have an effect on the final result. In the GC/MS analyze, we could get minor constituents of $8 \mathrm{ppm}$ indene, $48 \mathrm{ppm}$ indole, $23 \mathrm{ppm}$ quinoline and 20 ppm iso-quinoline in company $\mathrm{C}$ product, but those could not be found almost in $\mathrm{N}$-company product. Mothball of product from $\mathrm{N}$ company have more thianaphthene than its in $\mathrm{C}$ company product. The retention time of $7.438 \mathrm{~min}$. and $8.841 \mathrm{~min}$. are represent as indene and indole, respectively. Color mothball of $\mathrm{C}$ company product have more indene and indole than $\mathrm{N}$ company product.

In addition, we found dark solid formed on the surface of color mothball after UV-light test. Thus, Figure 8 shows the GC/MS chromatogram of the dark solid. These new structure were found in mothball after UV-light test. We conjecture that reason is mothball structure of dye and essences had changed by high energy of UV light. 
Janie pigment $1 \mathrm{~T}$

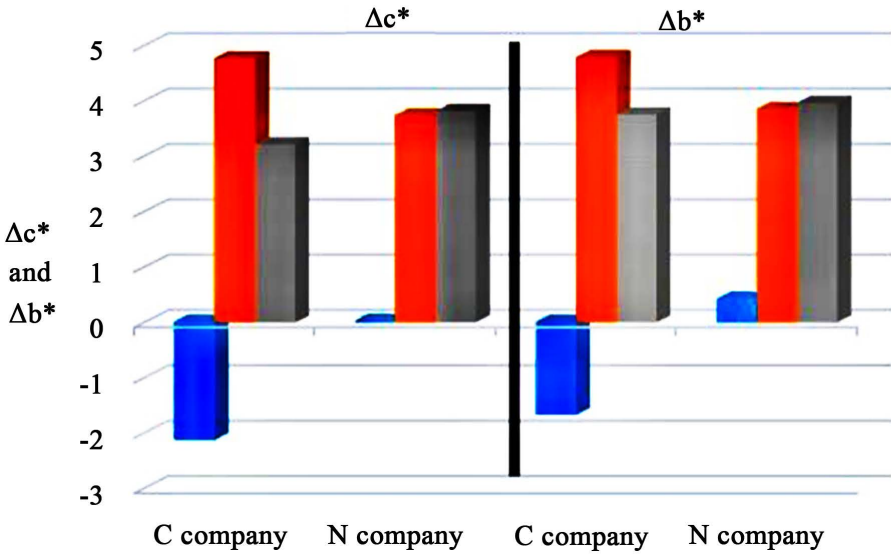

- sunflower

ginger lily

- lavender

(a)

Janie pigment 187

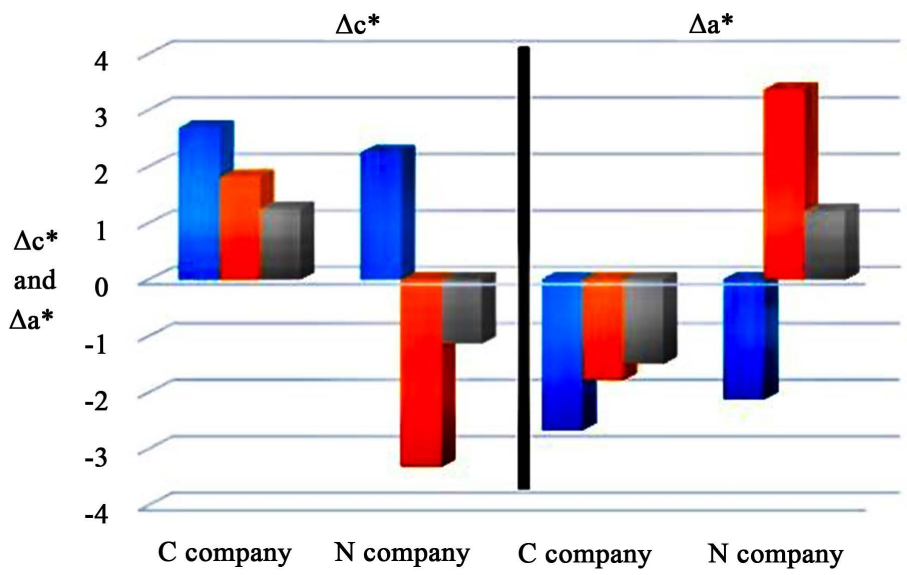

- sunflower

ainger lily

- lavender

(b)

C.I. $45430: 1$

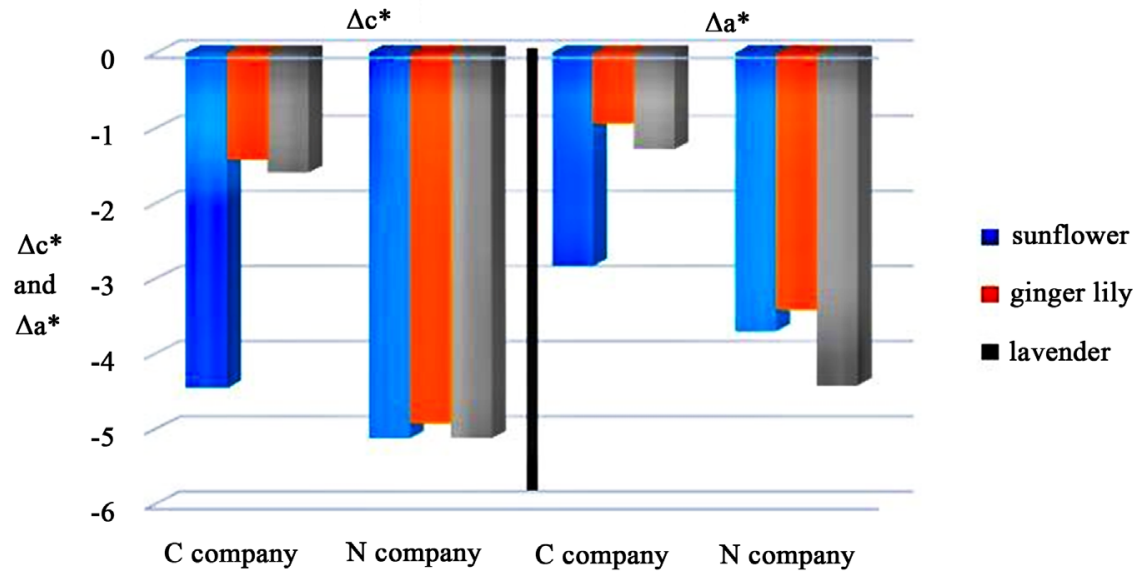

(c)

Figure 4. Comparison of the difference of $\mathrm{L}^{\star}, \mathrm{a}^{\star}, \mathrm{b}^{\star}$ and $\mathrm{c}^{\star}$ value in color mothball. (a) Janie Pigment 1T of yellow series (b) Janie Pigment 187 of green series (c) C.I. 45430:1 of red series. 


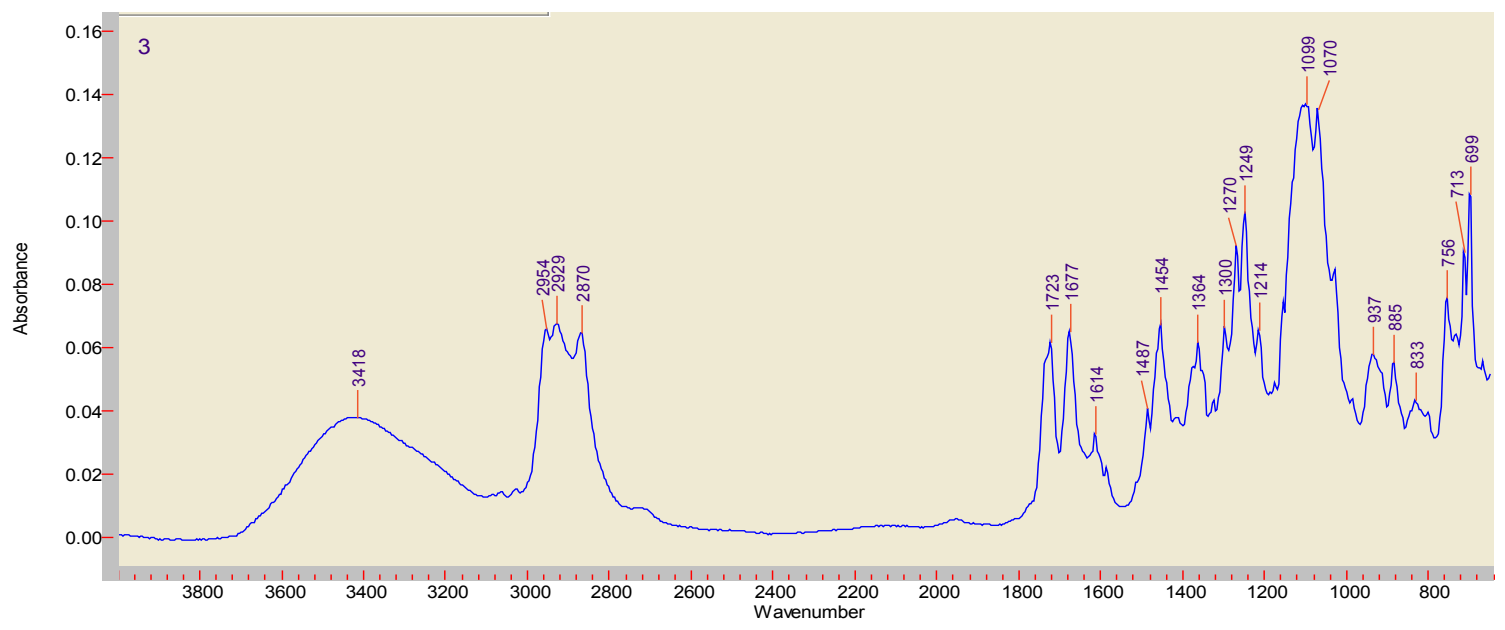

Figure 5. The fragrance of sunflower essences analyzed from Fourier transform infrared spectroscopy.

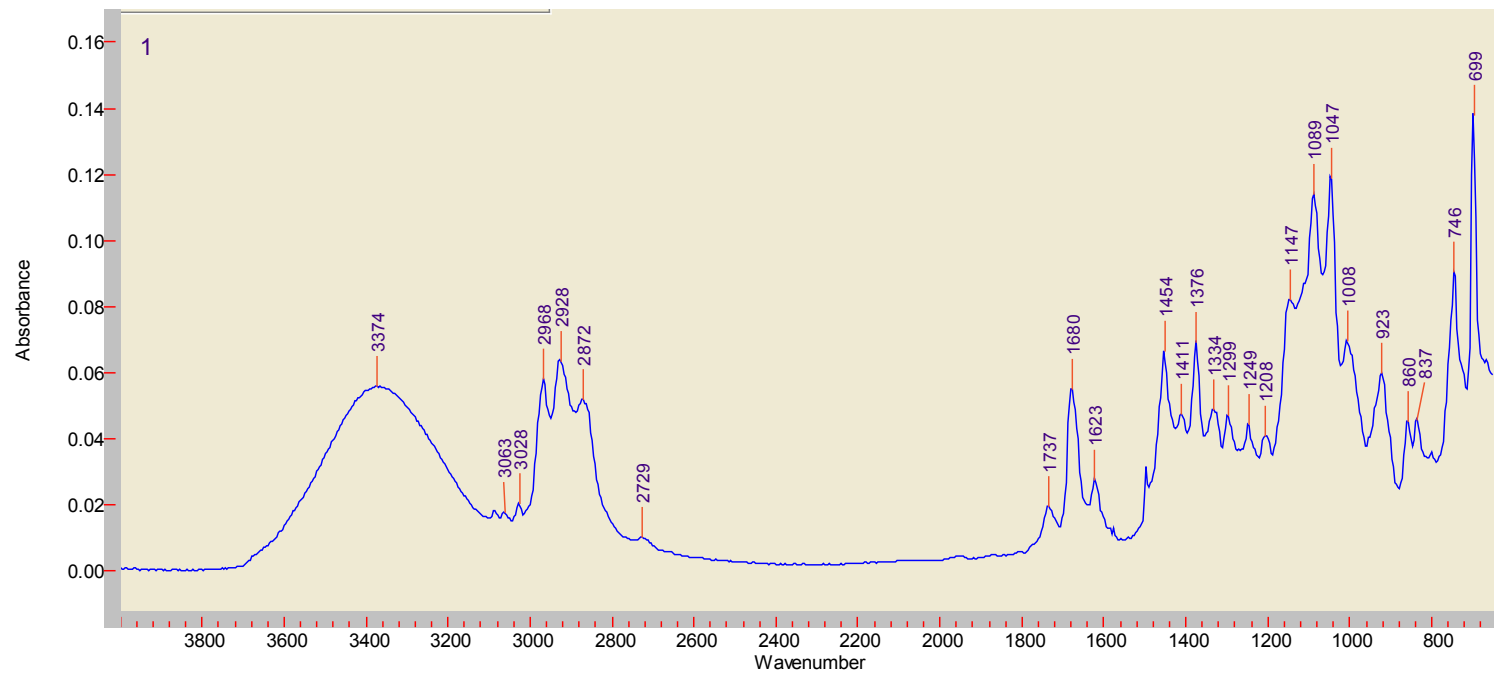

Figure 6. The fragrance of ginger lily essences analyzed from Fourier transform infrared spectroscopy.

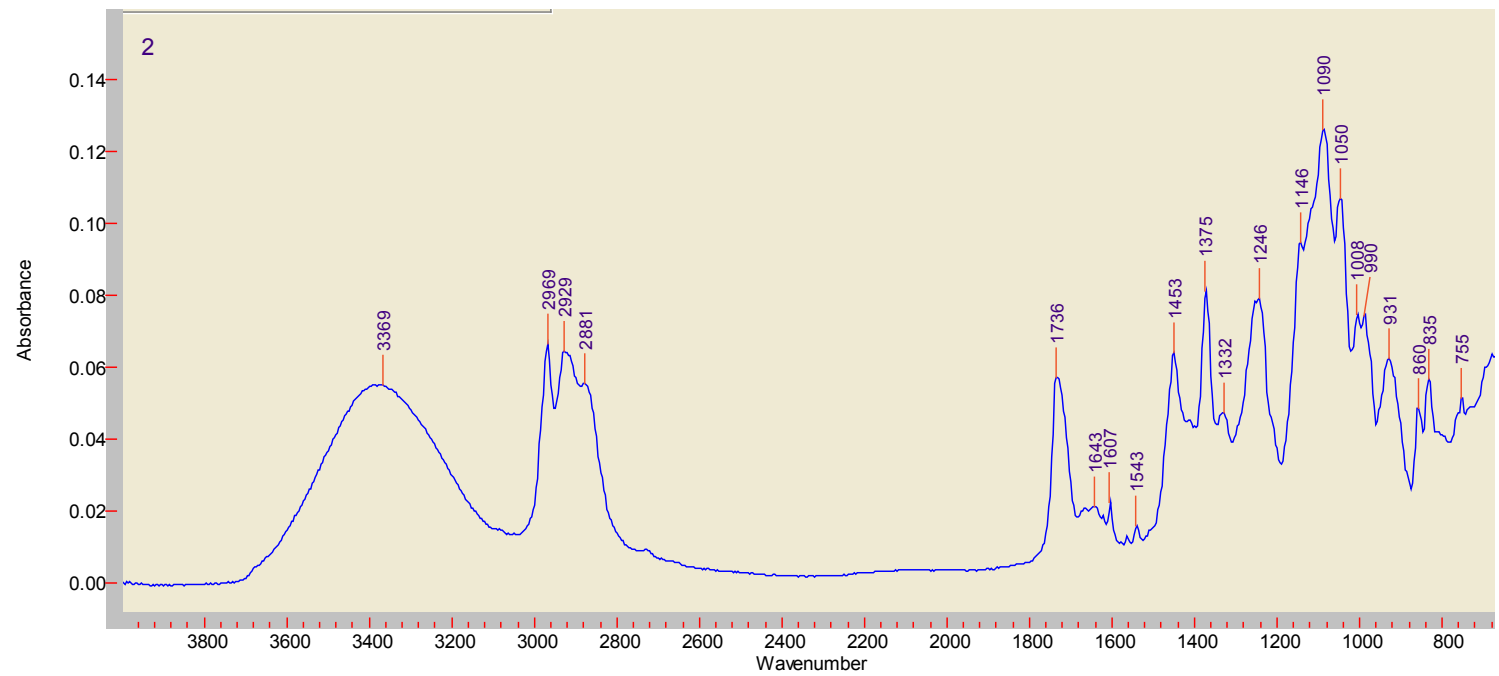

Figure 7. The fragrance of lavender essences analyzed from Fourier transform infrared spectroscopy. 


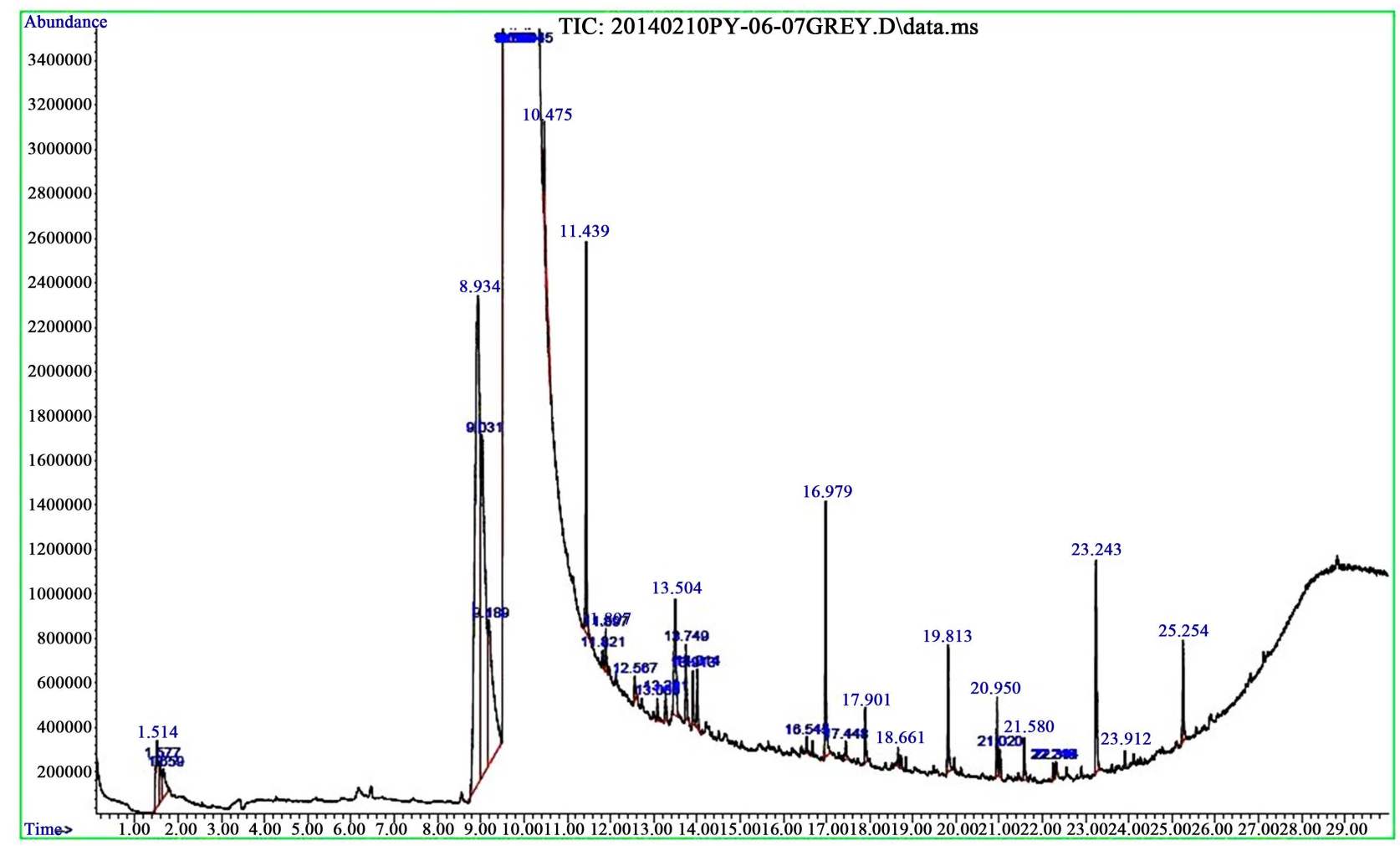

Figure 8. GC/MS chromatogram of dark solid formed on the surface of color mothball after UV-light test.

Table 5. The variety of vibration and rotation group from Fourier transform infrared spectroscopy.

\begin{tabular}{cccc}
\hline Classification & Group & Bond & Rang cm ${ }^{-1}$ \\
\hline \multirow{3}{*}{ Alkanes } & $\mathrm{R}-\mathrm{CH}_{3}$ & $\mathrm{C}-\mathrm{H}$ & $2972-2952,2882-2662,1475-1435,1380-1375$ \\
& $\mathrm{C}-\left(\mathrm{CH}_{3}\right)_{2}$ & $\mathrm{C}-\mathrm{C}$ & $1175-1165,1160-1135$ \\
& $\mathrm{C}-\left(\mathrm{CH}_{3}\right)_{3}$ & $\mathrm{C}-\mathrm{C}$ & $7255-1245,1250-1200$ \\
Alkenes & $\mathrm{R}-\mathrm{C}-\left(\mathrm{CH}_{2}\right)_{4}-\mathrm{O}$ & $\mathrm{C}-\mathrm{C}$ & $342-734$ \\
Alcohols & $\mathrm{CH}=\mathrm{CH} \mathrm{Cis}$ & $\mathrm{C}-\mathrm{H}, \mathrm{C}=\mathrm{C}$ & $3040-3010,730-650,1662-1631$ \\
& $(\mathrm{R})_{3}-\mathrm{C}-\mathrm{O}-\mathrm{H}$ & $\mathrm{O}-\mathrm{H}, \mathrm{C}-\mathrm{O}$ & $1685-1665$ \\
Ketones & $\mathrm{C}=\mathrm{C}-\mathrm{COR}$ & $\mathrm{C}=\mathrm{O}$ & $1690-1660$ \\
& Quinones & $\mathrm{C}=\mathrm{O}$ & $1350-1140$ \\
Halogens & Ring CF & $\mathrm{C}-\mathrm{F}$ & $1100-1000$ \\
Silicons & $\mathrm{Si}-\mathrm{O}-\mathrm{Si}, \mathrm{Si}-\mathrm{O}-\mathrm{C}$ & $\mathrm{Si}-\mathrm{O}-\mathrm{Si}, \mathrm{Si}-\mathrm{O}-\mathrm{C}$ & $13200,1410-1310,1210-11075-1000$ \\
Sulfur & $\mathrm{C}-\mathrm{SO} \mathrm{O}_{2}-\mathrm{O}-\mathrm{C}$ & $\mathrm{S}=\mathrm{O}, \mathrm{S}-\mathrm{O}, \mathrm{S}-\mathrm{C}$ & $1375-1335,1195-1165,1020-850,830-690,700-600$ \\
\hline
\end{tabular}

Table 6. The original compositions of mothball from $\mathrm{N}$ company and $\mathrm{C}$ company.

\begin{tabular}{cccc}
\hline No. & Component & N Company & C Company \\
\hline $\mathbf{1}$ & Naphthalene, $\%$ & 99.4 & 99.6 \\
$\mathbf{2}$ & Thianaphthene, $\%$ & 0.5 & 0.3 \\
$\mathbf{3}$ & Phenol, ppm & 5.0 & 1.0 \\
$\mathbf{4}$ & Indole, ppm & 9.0 & 48.0 \\
$\mathbf{5}$ & Quinoline, ppm & Nil. & 23.0 \\
$\mathbf{6}$ & Iso-quinoline, ppm & Nil. & 20.0 \\
$\mathbf{7}$ & Indene, ppm & Nil. & 8.0 \\
$\mathbf{8}$ & $\beta$-MN, ppm & Nil. & 2.0 \\
$\mathbf{9}$ & Unknows, ppm & 9.0 & 6.0 \\
\hline
\end{tabular}


Figure 9 shows the structure and properties of dark solid in mothball after UV-light test. It is possible to have environmental pollution as well as adverse human health. Therefore, the volatility gas of mothball is unpleasant and worried in commercial manufacturing. [13]

\section{Conclusion}

Naphthalene is a polycyclic aromatic hydrocarbon that is commonly encountered in indoor and outdoor environments. It is a component of crude oil, and it is also a product of natural combustion. A significant source of non-occupational exposures in residential settings is thought to be from the use of naphthalene-based products, particularly mothballs. Naphthalene mothballs contain above $99.4 \%$ naphthalene and else product including in thianaphthene. From the experimental studies, the mothball after UV-light test the color was darker than original. This is due to the volatility matter of color mothball. In other words, the unit volume of dye in color mothball is increased. Thus $\mathrm{K} / \mathrm{S}$ value is increased after UV-light test. From the retention time of GC/MS, we can get original composition of mothball from $\mathrm{N}$ and $\mathrm{C}$ company product, and the product from $\mathrm{C}$ company have more indene, indole, iso-quinoline and quinoline than $\mathrm{N}$ company due to minor constituents .The dark solid formed on the surface of color mothball after UV-light test were found. We can estimate the appearance of mothball structure by adding dye and essences, and then observe the appearance

\begin{tabular}{|c|c|c|c|c|c|}
\hline \multirow[b]{2}{*}{$\begin{array}{l}\text { Peak } \\
\text { No. }\end{array}$} & \multirow{2}{*}{$\begin{array}{c}\text { GC } \\
\text { Retentio } \\
\text { n Time }\end{array}$} & \multicolumn{3}{|c|}{ GC/MS } & \multirow[b]{2}{*}{ Risk Phrases } \\
\hline & & Mass $(\mathrm{m} / \mathrm{e})$ & $\begin{array}{c}\text { Molecular } \\
\text { formula }\end{array}$ & Molecular structure & \\
\hline 1 & 8.934 & $\begin{array}{c}126.9\left(\mathrm{M}^{+}\right) \\
92.0\left(\mathrm{C}_{6} \mathrm{H}_{4} \mathrm{NH}_{2}\right)^{+}, \\
65.0\left(\mathrm{C}_{5} \mathrm{H}_{5}\right)^{+},\end{array}$ & $\mathrm{C}_{6} \mathrm{H}_{6} \mathrm{ClN}$ & & $\begin{array}{c}\mathrm{R} 22 \\
\mathrm{R} 45 \\
\mathrm{R} 20 / 21 / 22\end{array}$ \\
\hline 2 & 9.031 & $\begin{array}{c}126.9\left(\mathrm{M}^{+}\right) \\
92.0\left(\mathrm{C}_{6} \mathrm{H}_{4} \mathrm{NH}_{2}\right)^{+}, \\
65.0\left(\mathrm{C}_{5} \mathrm{H}_{5}\right)^{+}\end{array}$ & $\mathrm{C}_{6} \mathrm{H}_{6} \mathrm{ClN}$ & & $\begin{array}{c}\text { R45 } \\
\text { R48 } \\
\text { R26/27 } \\
\end{array}$ \\
\hline 3 & 9.189 & $\begin{array}{c}134.1\left(\mathrm{M}^{+}\right) \\
108.1\left(\mathrm{C}_{6} \mathrm{H}_{4} \mathrm{~S}\right)^{+} \\
89.1\left(\mathrm{C}_{6} \mathrm{H}_{4} \mathrm{CH}_{2}\right)^{+}\end{array}$ & $\mathrm{C}_{7} \mathrm{H}_{4} \mathrm{CINO}$ & & $\begin{array}{c}\text { R26 } \\
\text { R35 } \\
\text { R37 } \\
\text { R42 } \\
\text { R36/37/38 }\end{array}$ \\
\hline 4 & 10.165 & $\begin{array}{c}134.1\left(\mathrm{M}^{+}\right) \\
105.1\left(\mathrm{C}_{6} \mathrm{H}_{4} \mathrm{CH}_{2} \mathrm{O}\right)^{+} \\
77.1\left(\mathrm{C}_{6} \mathrm{H}_{6}\right)^{+} \\
\end{array}$ & $\mathrm{C}_{8} \mathrm{H}_{6} \mathrm{~S}$ & & $\begin{array}{c}\mathrm{R} 22 \\
\mathrm{R} 51 / 53\end{array}$ \\
\hline 5 & 11.439 & $\begin{array}{c}148.1\left(\mathrm{M}^{+}\right) \\
104.1\left(\mathrm{C}_{6} \mathrm{H}_{4} \mathrm{CO}\right)^{+} \\
76.1\left(\mathrm{C}_{6} \mathrm{H}_{4}\right)^{+}\end{array}$ & $\mathrm{C}_{8} \mathrm{H}_{4} \mathrm{O}_{3}$ & & $\begin{array}{c}\mathrm{R} 22 \\
\mathrm{R} 37 / 38 \\
\text { R41 } \\
\text { R42/43 } \\
\end{array}$ \\
\hline 6 & 16.979 & $\begin{array}{c}238\left(\mathrm{M}^{+}\right) \\
89.0\left(\mathrm{C}_{4} \mathrm{H}_{8} \mathrm{OOH}\right)^{+} \\
45.0\left(\mathrm{C}_{2} \mathrm{H}_{4} \mathrm{OH}\right)^{+}\end{array}$ & $\mathrm{C}_{10} \mathrm{H}_{22} \mathrm{O}_{6}$ & & $\mathrm{R} 36 / 37 / 38$ \\
\hline 7 & 17.901 & $\begin{array}{c}278\left(\mathrm{M}^{+}\right) \\
148.9\left(\mathrm{C}_{6} \mathrm{H}_{5} \mathrm{C}_{3} \mathrm{H}_{3} \mathrm{O}_{2}\right)^{+}\end{array}$ & $\mathrm{C}_{16} \mathrm{H}_{22} \mathrm{O}_{4}$ & & $\begin{array}{l}\text { R50/53 } \\
\text { R62 } \\
\text { R63 } \\
\end{array}$ \\
\hline 8 & 19.813 & $\begin{array}{c}282\left(\mathrm{M}^{+}\right) \\
89.1\left(\mathrm{C}_{4} \mathrm{OH}_{8} \mathrm{OH}\right)^{+} \\
45.1\left(\mathrm{C}_{2} \mathrm{H}_{4} \mathrm{OH}\right)^{+}\end{array}$ & $\mathrm{C}_{12} \mathrm{H}_{26} \mathrm{O}_{7}$ & & $\begin{array}{c}\text { R25 } \\
\text { R27 } \\
\text { R43 } \\
\text { R21/22 } \\
\end{array}$ \\
\hline 9 & 25.254 & $\begin{array}{c}321.6\left(\mathrm{M}^{+}\right) \\
249.8\left(\mathrm{C}_{12} \mathrm{H}_{7} \mathrm{Cl}_{2} \mathrm{~N}_{2}\right)^{+} \\
124.9\left(\mathrm{C}_{6} \mathrm{H}_{2} \mathrm{ClNH}_{2}\right)^{+}\end{array}$ & $\mathrm{C}_{12} \mathrm{H}_{8} \mathrm{Cl}_{4} \mathrm{~N}_{2}$ & & $\begin{array}{c}\text { R48 } \\
\text { R48/23/24 }\end{array}$ \\
\hline
\end{tabular}

Figure 9. The structure and properties of dark solid in mothball after UV-light test. 
change by high energy of UV light. In FT-IR analysis, fragrance of three essences (sunflower, ginger lily and lavender of essences) has carboxyl structure, long alkyl group, and C-F bond. From the above experimental results, we think color mothball using dye of Janie pigment $1 \mathrm{~T}$ with sunflower essences, C.I. 45430:1 with ginger lily essences and Janie pigment 187 with lavender essences have the better color fastness.

\section{Conflicts of Interest}

There is no conflict of interest regarding the publication of this paper.

\section{Funding}

The research was not written as a project, so no research funding was requested.

There is no funding statement of this paper.

\section{Statement}

Data sharing not applicable to this article as no datasets were generated or analysed during the current study.

\section{References}

[1] Geriego, F.Y., Bogen, K.T., Price, P.S. and Weed, D.L. (2008) Exposure Epidemiology and Human Cancer Incidence of Naphthalene. Regulatory Toxicology and Pharmacology, 51, 22-26.

https://sciencedirect.com/science/article/pii/S0273230008000263 https://doi.org/10.1016/j.yrtph.2008.02.003

[2] Sudakin, D.L., Stone, D.L. and Power, L. (2011) Naphthalene Mothballs: Emerging and Recurring Issues and Their Relevance to Environmental Health. Current Opinion in Toxicology, 7, 13-19. https://ncbi.nlm.nih.gov/pmc/articles/PMC3850774/

[3] Kusch, P. (2017) Application of Gas Chromatography/Mass Spectrometry (GC/MS) and Pyrolysis-Gas Chromatography/Mass Spectrometry (Py-GC/MS) in Failure Analysis in the Automotive Industry. Engineering Failure Analysis, 82, 726-732. https://sciencedirect.com/science/article/pii/S1350630716308469 https://doi.org/10.1016/j.engfailanal.2017.06.033

[4] Preuss, R., Angerer, J. and Drexler, H. (2003) Naphthalene-An Environmental and Occupational Toxicant. International Archives of Occupational and Environmental Health, 76, 556-576.

https://researchgate.net/publication/10611129_Naphthalene_-_An_environmental_ and_occupational_toxicant https://doi.org/10.1007/s00420-003-0458-1

[5] International Color Consortium, Specification ICC.1:2004-10 Image 4. Technology colour Management-Architecture, Profile Format, 2006. http://color.org/icc1v42_2006-05.pdf

[6] Great Britain, COLOR INDEX, The Society of Dyes and Colourists American Association of Textile Chemists and Colorists, 1969, 3494.

[7] Hunter, R.S. (1948) Proceedings of the Thirty-Third Annual Meeting of the Optical Society of America. Journal of the Optical Society of America, 38, 1092-1106. https://www.osapublishing.org/josa/abstract.cfm?uri=josa-38-12-1092 
https://doi.org/10.1364/JOSA.38.001092

[8] Parab, R.H., Patel, K.D., Desai, D.J. and Dixit, B.C. (2016) Synthesis and Dyeing Performance of Bisazo Disperse Dyes Based on 3-[4-(4-amino-2-chlorophenoxy)anilino]phenol. Journal of Saudi Chemical Society, 20, 523-529.

https://sciencedirect.com/science/article/pii/S1319610312001214 https://doi.org/10.1016/j.jscs.2012.07.012

[9] Sayed, A.Z., Aboul-Fetouh, M.S. and Nassar, H.S. (2012) Synthesis Biological Activity and Dyeing Performance of Some Novel Azo Disperse Dyes Incorporating Pyrazolo[1,5-a]pyrimidines for Dyeing of Polyester Fabrics. Journal of Molecular Structure, 1010, 146-151.

https://sciencedirect.com/science/article/pii/S002228601100929X https://doi.org/10.1016/j.molstruc.2011.11.046

[10] Sener, I., Karei, F. and Ertan, N. (2006) Synthesis and Investigations of the Absorption Spectra of Hetarylazo Disperse Dyes Derived from 2,4-Quinolinediol. Dyes and Pigments, 70, 143-148.

https://sciencedirect.com/science/article/pii/S0143720805001592 https://doi.org/10.1016/j.dyepig.2005.05.003

[11] Ki, Y., Zhang, S., Yang, J., Jiang, S. and Li, Q. (2008) Synthesis and Application of Novel Crosslinking Polyamine Dyes with Good Dyeing Performance. Dyes and Pigments, 76, 508-514.

https://sciencedirect.com/science/article/pii/S014372080600413X https://doi.org/10.1016/j.dyepig.2006.10.012

[12] Xu, H., Tang, B.T. and Zhang, S.F. (2011) Synthesis and Dyeing Performance of a Novel Polycarboxylic Acid Azo Dye. Chinese Chemical Letters, 22, 424-426. https://sciencedirect.com/science/article/pii/S1001841710004638 https://doi.org/10.1016/j.cclet.2010.11.010

[13] Esparza, X., Moyano, E., Coxialls, J.R. and Galceran, M.T. (2013) Determination of naphthalene-Derived Compounds in Apples by Ultra-High Performance Liquid Chromatography-Tandem Mass Spectrometry. Analytica Chimica Acta, 782, 28-36. https://sciencedirect.com/science/article/pii/S0003267013004984 https://doi.org/10.1016/j.aca.2013.03.067 